\title{
ENRICHMENT OF GRAIN HYDROLYSATE WITH BACTERIAL PROTEIN
}

\author{
Kiribayeva A.K., Silayev D.V., Baduanova S.D., Khassenov B.B. \\ National Center for Biotechnology \\ 13/5, Korgalzhyn road, Nur-Sultan, 010000, Kazakhstan \\ asel_january@mail.ru
}

\begin{abstract}
Feed enrichment with valuable nutrients for animals is a priority for the agricultural industry of Kazakhstan. This paper presents the technology of grain processing into feed preparation using lactic acid bacteria. Enzymatically hydrolyzed grain was a growing medium for the growth of lactic acid bacteria of the genus Lactobacillus. Cultivation of L.plantarum and L.salivarius bacteria in the saccharified grain hydrolysate helped to increase the total protein content in preparations by $26-45 \%$ and the enrichment of the feed preparation with glucose, lactic acid, and vitamins. This technology of grain processing into the feed preparation would be useful in terms of deep processing of grain and obtaining feed preparations containing important nutrient ingredients. bacteria

Keywords: bacterial protein, enrichment, grain, feed preparation, lactic acid

\section{INTRODUCTION}

According to the Statistics Committee of the Ministry of National Economy of the Republic of Kazakhstan in 2017, the sown area of agricultural crops amounted to more than 21.0 million hectares in Kazakhstan. The main share in the sowing structure is occupied by cereals up to $70 \%$. The wheat accounts for about $55 \%$ of the dominating share. Against the background of available data on yield, the proportion of processed products from grain crops remains very low. The existing enterprises conducting the deep processing of grain make it possible to process no more than 120 thousand tons of grain. For the transition of the industrial economy of Kazakhstan to a new technological level, the Government of the Republic of Kazakhstan was tasked to bring the volume of deep processing of grain to 1 million tons by 2021. This indicator is expected to be achieved through the modernization of existing and construction of new enterprises in the grainsowing regions of the country. By 2021, the volume of deep processing of grain is expected to increase 9 fold, and the volume of export of products will amount to 300 million US dollars.

Whereas the $1^{\text {st }}$ and $2^{\text {nd }}$ class wheat has a high value in the food industry, the $3^{\text {rd }}$ and $4^{\text {th }}$ class wheat is mainly used in the feeding of farm animals. It is known that wheat is characterized by a high starch content $(60 \%)$, second only to corn $(65 \%)$ in this indicator, but the content of digestible vegetable protein (at the level of 15\%) is not enough for a full-fledged human and animal diet. In agriculture, the current shortage of feed resources for mammals, birds and fish is aggravated by a significant global shortage of feed protein in the range of 45-57 million tons per year. The main sources of feed protein currently are soybean and sunflower meal, feed yeast, bone meal and fish meal. A rather considerable alternative to existing technologies of enriching feed with protein preparations can be a bacterial protein characterized by a high degree of assimilation.
\end{abstract}


The aim of the work is to obtain a feed preparation based on grain enriched with bacterial protein, glucose, lactic acid bacteria and products of their metabolism.

\section{Materials and methods}

The grains of the 3rd and 4th grade from domestic production of the 2018 harvest were used in this research. The lactic acid bacteria Lactobacillus plantarum and Lactobacillus salivarius from the laboratory collection, isolated from sauerkraut and the gastrointestinal tract of chicken, respectively, were used in the work. Enzyme preparations Amylosubtilin and Glukavamorin (Sibbiopharm) containing thermostable amylase and glucoamylase from Bacillus subtilis and Aspergillus awamori, respectively, were used. The qualitative determination of starch was carried out with a starch iodine starch test under standard conditions $\left(+37^{\circ} \mathrm{C}, 10 \mathrm{~min}\right)$ [1]. The glucose content in the samples was performed using the glucose oxidase method [2] using the commercial kit "Vital". The content of lactic acid in the samples was determined by the lactate oxidase method [3] also using the commercial kit "Vital". Determination of total protein content was carried out according to the Kjeldahl method [4] in Astana branch of the Kazakh Research Institute of Processing and Food Industry LLP. The titer of lactic acid microorganisms was determined by Koch method on MRS agar medium and expressed in colony-forming units per gram of sample (CFU/g).

\section{Obtainment of grain hydrolysate}

$1 \mathrm{~kg}$ of each grade of grain was milled to obtain particles of a size of not more than 500 microns. Hereafter, prepared ground grain was added to 3 liters of hot water $\left(+90^{\circ} \mathrm{C}\right)$ in order to obtain a hydronic module 3:1. The solution was incubated for 1 hour with constant stirring and a temperature of $+85^{\circ} \mathrm{C}-+90^{\circ} \mathrm{C}$. After incubation, the solution was cooled to a temperature of $+75^{\circ} \mathrm{C}$ and 1 gram of Amylosubtilin was added. Starch liquefaction was carried out for 1.5 hours, after which the temperature was lowered to $+60^{\circ} \mathrm{C}$ and 1 gram of Glukavamorin was added. The saccharification step was carried out for 2 hours.

\section{Obtainment of samples}

On the medium MRS-broth production HiMedia (pepton 1\%, meat extract 1\%, yeast extract $0.5 \%$, glucose $2 \%$, tween- $800.1 \%$, ammonium citrate $0.2 \%$, sodium acetate $0.5 \%$, magnesium sulphate $0.01 \%$, manganese sulphate $0.005 \%$, sodium hydrogen phosphate $0.2 \%$ ) bacteria of L.plantarum and L.salivarius strains were grown at a temperature of $+37^{\circ} \mathrm{C}$ to achieve a titer of $10^{9} \mathrm{CFU} / \mathrm{ml}$. $200 \mathrm{ml}$ cultures of each type of bacteria were added to the grain hydrolysate. The culture of L.plantarum was introduced into the hydrolysate obtained from grain of the 3rd grade, and the culture of L.salivarius was introduced into the hydrolysate obtained from the grain of 4th grade. Cultivation of bacteria on grain hydrolysate was carried out in a dryair thermostat, without aeration, at a temperature of $+37^{\circ} \mathrm{C}$ for 60 hours. Upon completion of the cultivation, the substrate treated with bacteria was separated by centrifugation $\left(10,000 \times \mathrm{g},+4^{\circ}\right.$ C, 30 minutes), the fractions were dried: the spray-dried supernatant LPG-5 (Zonten Engeniering) at $+80^{\circ} \mathrm{C}-90^{\circ} \mathrm{C}$, sediment in a ShS-80-1 dry-heat cabinet at a temperature of +70 ${ }^{\circ} \mathrm{C}$ or under vacuum by freeze drying in a BETA 2-8 LD plus lyophilizer (Christ). At the final stage, the dry fractions were mixed to obtain two preparations: Preparation No. 1 - hydrolysate of grain grade 3, treated with L.plantarum bacteria, and Preparation No. 2 - hydrolysate of grain grade 4, treated with L. salivarius bacteria. The obtained samples were analyzed for starch, glucose, protein, lactic acid. The titer of lactic acid bacteria was counted in lyophilisates.

\section{RESULTS AND DISCUSSIONS}


Determination of glucose and starch contents in the samples showed that after treatment of the grain with hot water, the starch releases effectively (Table 1). After hydrolysis and conversion, the presence of residual starch in the supernatant and sediment is not observed.

Table 1. Starch and glucose content in samples

\begin{tabular}{|c|c|c|}
\hline $\begin{array}{r}\text { Sample } \\
\end{array}$ & Starch & Glucose \\
\hline Steamed milled $3^{\text {rd }}$ grade grain & + & - \\
\hline Steamed milled $4^{\text {th }}$ grade grain & + & - \\
\hline Precipitate of ${ }^{\text {rd }}$ gradegrain's hydrolysate & - & + \\
\hline Supernatantof $3^{\text {rd }}$ grade grain's hydrolysate & - & + \\
\hline Precipitate of $4^{\text {th }}$ grade grain'shydrolysate & - & + \\
\hline Supernatantof $4^{\text {th }}$ grade grain's hydrolysate & - & + \\
\hline
\end{tabular}

Quantification of glucose in the samples showed that average glucose yield is $2.6-3.3 \%$ for precipitation and $58 \%$ for supernatant (Table 2).

Table 2. Starch content in fractions

\begin{tabular}{|l|c|l|}
\hline \multicolumn{2}{|c|}{ Sample } & Glucose, \% \\
\hline \multirow{2}{*}{$\begin{array}{l}\text { Hydrolysate of } 3 \\
\text { grade grain }\end{array}$} & precipitation dried at $+70^{\circ} \mathrm{C}$ & 3.3 \\
\cline { 2 - 3 } & Lyophilisate & 3.2 \\
\cline { 2 - 3 } & Supernatant & 58.0 \\
\hline \multirow{2}{*}{$\begin{array}{l}\text { Hydrolysate of } 4 \\
\text { grade grain }\end{array}$} & Precipitation dried at $+70^{\circ} \mathrm{C}$ & 2.8 \\
\cline { 2 - 3 } & Lyophilisate & 2.6 \\
\cline { 2 - 3 } & Supernatant & 58.0 \\
\hline
\end{tabular}

After mixing the dry components and obtaining the preparations, the total protein content in the initial grain and preparations was $10.0-10.3 \%$ and $12.6-14.9 \%$, respectively (table 3 ).

Table 3. Crude protein content in preparations according to the method of Kjeldahl.

\begin{tabular}{|l|l|}
\hline \multicolumn{1}{|c|}{ Samples } & \multicolumn{1}{|c|}{ Protein content $(\%)$} \\
\hline $3^{\text {rd }}$ grade grain & $10.3 \%$ \\
\hline Processed L. plantarum hydrolysate of $3^{\text {rd }}$ grade grain & $14.9 \%$ \\
\hline $4^{\text {th }}$ grade grain & $10.0 \%$ \\
\hline Processed L.salivarius hydrolysate of $4^{\text {th }}$ grade grain & $12.6 \%$ \\
\hline
\end{tabular}

Table 4 illustrates the summary data on the content of glucose and lactic acid, the titer of lactic acid bacteria in the preparations, the data on the change of protein. The content of lactic acid microorganisms was about $10^{6}-10^{7} \mathrm{CFU} / \mathrm{g}$ in the lyophilisates received. The protein content was increased of $26-45 \%$ in preparations received. The preparations contain lactic acid, which is a product of the metabolism of lactic acid bacteria at the level of $0.25-0.26 \%$.

Table 4. The titer of lactic acid bacteria, glucose and lactic acid content, increasing the protein content.

\begin{tabular}{|c|c|c|c|c|c|c|c|}
\hline \multirow[t]{2}{*}{ Preparation } & \multirow{2}{*}{$\begin{array}{l}\text { Classes } \\
\text { of } \\
\text { grain }\end{array}$} & \multirow[t]{2}{*}{ Bacterium } & \multirow{2}{*}{$\begin{array}{l}\text { Titre, } \\
\text { GFU/g }\end{array}$} & \multicolumn{3}{|c|}{ Content } & \multirow{2}{*}{$\begin{array}{l}\text { Protein } \\
\text { increasing }\end{array}$} \\
\hline & & & & Glucose & $\begin{array}{l}\text { Lactic } \\
\text { acid }\end{array}$ & Protein & \\
\hline Preparation 1 & 3 & L.plantarum & $1.2^{*} 10^{\prime}$ & $30 \%$ & $0.25 \%$ & $14.9 \%$ & For $45 \%$ \\
\hline Preparation 2 & 4 & L.salivarius & $0.7 * 10^{7}$ & $30 \%$ & $0.26 \%$ & $12.6 \%$ & For $26 \%$ \\
\hline
\end{tabular}




\section{CONCLUSION}

It is known that the preliminary stage of starch processing is its release from grains with hot water or steam treatment at pressure $\left(90^{\circ} \mathrm{C}-105^{\circ} \mathrm{C}\right)$. Using a duty of water of $3: 1$ with hot water $\left(+90^{\circ} \mathrm{C}\right)$ allows to release starch from the grain without steam. At the stage of starch liquefaction, which is a dextrinization - hydrolysis of the substrate with $\alpha$-amylase, the end products of this stage are maltodextrins. Control on the content of residual starch by iodine dough showed that the proposed regime allowed hydrolysing grain starch as much as possible. The use of lactic acid bacteria for the treatment of the saccharified hydrolysate made it possible to obtain a preparation enriched with bacterial protein, lactic acid, glucose and lactic acid bacteria capable to act as probiotic microorganisms. The final product yield was: 755 grams of preparation No. 1 of $1 \mathrm{~kg}$ of grain class 3, fermented L. plantarum and 747 grams of preparation of No. 2 of $1 \mathrm{~kg}$ of grain class 4, fermented L.salivarius. The final titer of lactic acid microorganisms was 106-107 CFU/g. The total glucose content in both preparations is $30 \%$. The analysis shows that increase of protein in preparations of $26 \%-45 \%$ occurs mainly due to the bacterial mass of lactic acid bacteria, and not due to the protein from the growing medium. The calculation demonstrates that the addition of protein from the growing medium provides in the amount of less than $0.5 \%$ (in terms of the total weight of the drug: proteose peptone $-0.2 \%$; meat extract $0.2 \%$; yeast extract $0.05 \%$ ). The calculation shows that the addition of protein from the growing medium in the amount of less than $0.5 \%$ (in terms of the total weight of the drug: pepton $-0.2 \%$; meat extract $0.2 \%$; yeast extract $0.05 \%$ ). The calculation shows that the addition of protein from the growing medium gives less than $0.5 \%$ (based on the total weight of the preparation: proteose pepton $-0.2 \%$; meat extract $0.2 \%$; yeast extract $0.05 \%$ ). The preparations contain a significant amount of lactic acid (0.25-0.26\%) and vitamins, which are products of metabolism of lactic acid bacteria [5]. This technology of grain processing into the feed preparation is interesting in terms of deep processing of grain, enriching the feed with bacterial protein, low molecular weight metabolites, vitamins, and probiotic microorganisms.

\section{Acknowledgements}

This work was supported by the Science Committee of the Ministry of Education and Science of the Republic of Kazakhstan (Scientific Technical Program «Creating New Products and Innovative Biotechnologies for Agriculture and Veterinary» under the project «Development of technology for generation of strain producing recombinant carbohydrase»).

\section{REFERENCES}

1. Kamyshnikov V.S. Kliniko-biohimicheskaya laboratornaya diagnostika. Spravochnik. Minsk: Interpreservice, 2003, tom I, s.495 (Kamyshnikov V.S. Clinical and biochemical diagnostics. Handbook. Minsk:Interpreservice, 2003, vol.1, p.495).

2. Buzanovskii, V. A. Methods for the determination of glucose in blood. Part 2. Review Journal of Chemistry, 2015, vol. 5, no. 8, pp. 143- 191.

3. Smutok O., Karkovska M., Smutok H., Gonchar Mykhailo. Flavocytochrome b2-Based Enzymatic Method of L-Lactate Assay in Food Products. Scien. World J., 2013. https://doi: 10.1155/2013/461284.

4. Hanne K. Mæhre, Lars Dalheim, Guro K. Edvinsen, Edel O. Elvevoll, and Ida-Johanne Jensen. Protein determination - Method matters. Foods, 2018, vol.7, no.1. https://doi:10.3390/foods7010005.

5. Laiño J.E.,Juarez del Valle M.,Savoy de Giori G.,LeBlanc J.G. Development of a high folate concentration yogurt naturally bio-enriched using selected lactic acid bacteria. LWT Food Sci. Technol., 2013, vol. 54, pp.1-5. 


\title{
АСТЫҚТЫ БАКТЕРИЯЛЫҚ АҚУЫЗБЕН ӨНДЕУ ЖӘНЕ БАЙЫТУ
}

\author{
Кирибаева А.К., Силаев Д.В., Бадуанова С.Д., Хасенов Б.Б. \\ Ұлттық биотехнология орталыгы \\ Қорвалжын тас жоль, 13/5, Нұр-Сұлтан к., 010000, Қазақсстан \\ asel_january@mail.ru
}

\section{ТYЙІН}

Жануарларға арналған азықты құнды қоректік компоненттермен байыту Қазақстанның ауыл шаруашылығы өнеркәсібінің басым бағыты болып табылады. Бұл жұмыста сүтқышқылды бактерияларды пайдалана отырып, азықтық препаратқа астықты қайта өндеу технологиясы ұсынылған. Астықтың ферментативті гидролизаты Lactobacillus тектес сүт қышқылды бактериялар үшін өсіруші қоректік орта болды. L.plantarum және L.salivarius бактерияларын қантталған астық гидролизатында культивирлеу препараттардағы жалпы ақуыз кұрамының 26-45\%-ға ұлғаюына және азықтық препараттағы глюкоза, сүт қышқылы және витаминдердін байытуына ықпал етті. Азықтық препаратқа астықты қайта өңдеудің осы технологиясы астықты терең өндеу және құрамында маңызды қоректік ингредиенттері бар азықтық препараттарға қол жеткізу жағынан пайдалы болып табылады.

Негізгі сөздер: бактериялық ақуыз, байыту, астық, жемдік препарат, сүт қышқылды бактериялар

\section{ПЕРЕРАБОТКА И ОБОГАЩЕНИЕ ЗЕРНА БАКТЕРИАЛЬНЫМ БЕЛКОМ}

Кирибаева А.К., Силаев Д.В., Бадуанова С.Д., Хасенов Б.Б.

Национальный центр биотехнологии

Кургальжинское шоссе, здание 13/5, г. Нур-Султан, 010000, Казахстан asel_january@mail.ru

\section{АБСТРАКТ}

Обогащение кормов ценными питательными компонентами для животных является приоритетным направлением для сельскохозяйственной промышленности Казахстана. В данной работе представлена технология переработки зерна в кормовой препарат с использованием молочнокислых бактерий. Ферментативный гидролизат зерна являлся питательной средой для роста молочнокислых бактерий рода Lactobacillus. Культивирование бактерий L.plantarum и L.salivarius в осахаренном гидролизате зерна способствовало увеличению содержания общего белка в препаратах на 26-45 
\% и обогащению кормового препарата глюкозой, молочной кислотой и витаминами. Данная технология переработки зерна в кормовой препарат представляется интересной в плане глубокой переработки зерна и получения кормовых препаратов с содержанием важных питательных ингредиентов.

Ключевые слова: бактериальный белок, обогащение, зерно, кормовой препарат, кисломолочные бактерии. 